\title{
A Clutch of the False Tree Coral, Rhinobothryum bovallii Anderson 1916 (Squamata: Colubridae), in the Colombian Caribbean
}

\author{
Anibal J. Barreto-Martínez ${ }^{1}$ and Julián A. Rojas-Morales ${ }^{2}$ \\ Manu Adventures-Manu National Park, Calle Plateros 356, Cusco, Perú (anibalofidios@gmail.com) \\ ${ }^{2}$ Facultad de Ciencias Básicas, Corporación Universitaria Santa Rosa de Cabal (UNISARC), Campus Universitario “El Jazmín” Km 4 Vía Santa Rosa de Cabal - \\ Chinchiná, Caldas, Colombia (julian.herpetologia@gmail.com)
}

$\mathrm{O}$ viparous snakes lay eggs under logs and rocks, in the nests of ants, termites, and alligators, or in underground chambers excavated by other animals (e.g., Velásquez-Múnera et al. 2008; Baer et al. 2009; Nagy et al. 2017). However, such basic aspects of reproductive biology are unknown for many of the 886 Neotropical species of snakes (Guedes et al. 2017).

The False Tree Coral (Rhinobothryum bovallii) has a disjunct distribution across the lowland humid and pre-montane forests from Honduras to Ecuador (Savage 2002; Solórzano 2004; Rojas-Morales 2012; Natera-Numaw et al. 2015; Pazmiño-Otamendi 2017). Nests of this oviparous snake have been described only in captivity (Solórzano 2004; Hammack and Brinker 2008). Ecomorphologically, R. bovallii is an arboreal species (following the definition of Harrington et al. 2018) because it has an elongated and compressed body; it also is nocturnal, oviparous, and feeds on reptiles. As many as six eggs laid in January, February, and June take more than 120 days to hatch (Solórzano 2004; Hammack and Brinker 2008). We herein present, to the best of our knowledge, the first record of a nest in the wild in the South American Caribbean.
On 17 July 2012, we found a nest with three exposed eggs near Miraflores Village $\left(09^{\circ} 55^{\prime} 27.7926^{\prime N}\right.$, $75^{\circ} 05^{\prime} 37.3344^{\prime \prime W}$; elev. $167 \mathrm{~m}$ asl), Municipality of San Juan de Nepomuceno, Department of Bolívar, Colombia (Fig. 1). The eggs were $4 \mathrm{~m}$ from the edge of a small stream inside a tropical dry forest fragment (sensu Holdridge 1967). One of the eggs had already hatched. One of the remaining eggs $(56 \times 22 \mathrm{~mm})$ was collected and placed in a plastic box with vermiculite substrate, humidity around $50 \%$, and a temperature of $30^{\circ} \mathrm{C}$. Ten days later (27 July 2012), a hatchling with a prominent yolk and coloration like that of adults (Fig. 2) emerged from the egg. It measured $200 \mathrm{~mm}$ snout-vent length, $37 \mathrm{~mm}$ tail length, and weighed $18 \mathrm{~g}$. We released the hatchling at the original site of collection.

This record, in addition to other recent observations (see Table A1 in Martínez-Fonseca et al. 2019), confirms the presence of $R$. bovallii in the dry forests of the Colombian Caribbean, indicating that it is not restricted to lowland humid and pre-montane forests. Also, this record, the first for the Department of Bolívar, fills a gap between the northeastern Colombian locality (Arimaca, Santa Marta,

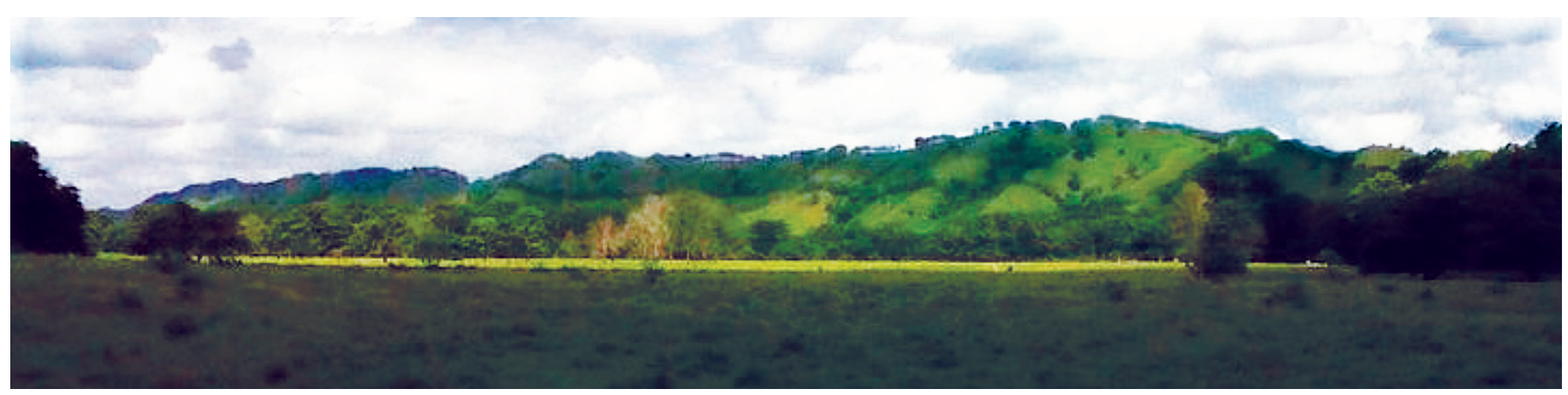

Fig. 1. Habitat of the False Tree Coral (Rhinobothryum bovalli) in the Municipality of San Juan Nepomuceno, Department of Bolívar, Colombia. Note the extended deforestation in the area. Photograph by Aníbal Barreto-Martínez. 

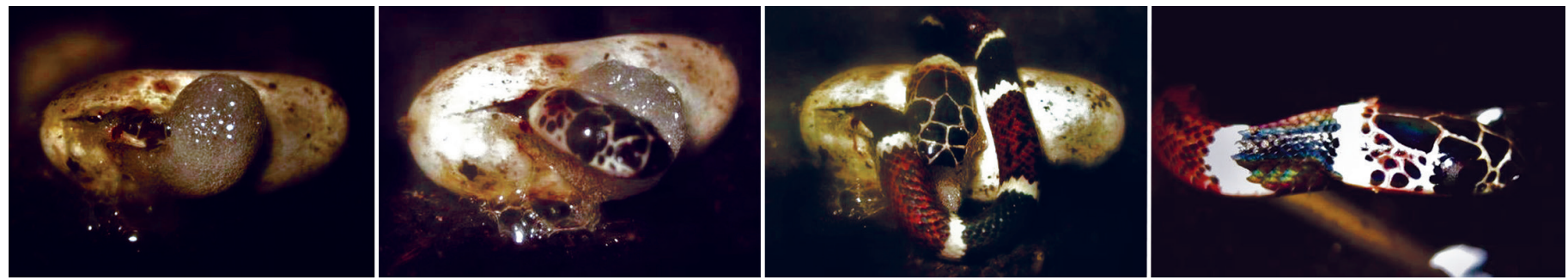

Fig. 2. Hatching sequence of a newborn False Tree Coral (Rhinobothryum bovallii) in captivity. Photographs by Aníbal Barreto-Martínez.

Department of Magdalena; https://www.inaturalist.org/ observations/16216599) and the nearest record to the south in Tierralta, Department of Córdoba (Rojas-Morales 2012).

The compressed bodies and elongated tails of arboreal snakes limit females to a smaller numbers of eggs compared to typical terrestrial and aquatic species (Vitt and Vangilder 1983; Lillywhite and Henderson 1993). In principle, this could increase the vulnerability of arboreal species to anthropogenic changes in habitats. Although on the IUCN Red List as a species of Least Concern, Arredondo et al. (2017) listed a series of threats to $R$. bovallii, all involving deforestation. While not considered major threats at present, increased research efforts to better understand fundamental aspects of the life history of the species are necessary for accurately assessing the future effects of these threats.

\section{Acknowledgements}

We thank Dairo Gómez Serje for all the fieldwork facilities. Thanks also to Héctor Ramírez Chávez for helpful comments on a previous draft of the manuscript.

\section{Literature Cited}

Arredondo, J.C., D.F. Cisneros-Heredia, G. Rivas, J. Sunyer, and J.H. Townsend. 2017. Rhinobothryum bovallii. The IUCN Red List of Threatened Species 2017: e.T177498A1489023. <http://doi.org/10.2305/IUCN.UK.2017-2.RLTS. T177498A1489023.en>.

Baer, B., S.P.A. den Boer, D.J.C. Kronauer, D.R. Nash and J.J. Boomsma. 2009. Fungus gardens of the leafcutter ant Atta colombica function as egg nurseries for the snake Leptodeira annulata. Insectes Sociaux 56: 289-291.

Guedes, T.B., R.J. Sawaya, A. Zizka, S. Laffan, S. Faurby, R.A. Pyron, R.S. Bérnils, M. Jansen, P. Passos, A.L.C. Prudente, D.F. Cisneros-Heredia, H.B. Braz, C. de Nogueira, and A. Antonelli. 2017. Patterns, biases and prospects in the distribution and diversity of Neotropical snakes. Global Ecology and Biogeography 27: 14-21.
Hammack, S. and A. Brinker. 2008. Rhinobothryum bovallii (NCN). Reproduction. Herpetological Review 39 (1): 100-101.

Harrington, S.M., J.M. De Haan, L. Shapiro, and S. Ruane. 2018. Habits and characteristics of arboreal snakes worldwide: arboreality constrains body size but does not affect lineage diversification. Biological Journal of the Linnean Society 125(1): 61-71.

Holdridge, L.R. 1967. Life Zone Ecology. Revised Edition. Tropical Science Center, San José, Costa Rica.

Lillywhite, H.B. and R.W. Henderson. 1993. Behavioral and functional ecology of arboreal snakes. In: R.A. Seigel; J.T. Collins (eds.). Snakes: ecology and behavior. McGraw-Hill, New York.

Martínez-Fonseca, J.G., J. Loza, M. Fernández, M. Salazar-Saavedra, and J. Sunyer. 2019. First country record of Rhinobothryum bovallii (Andersson, 1916) (Squamata, Colubridae) from Nicaragua. Check List 15 (4): 555-563. https:// doi.org/10.15560/15.4.555

Nagy, Z.T., W. Dekonink, F. de Block, K. Yeo, K. Silue, and T. Delsinne. 2017. Oviposition of the snake Thelotornis kirtdlandii in a parabiotic ant nest. Salamandra 53(1): 167-170.

Natera-Mumaw, M., L.F. Esqueda-González, and M. Castelaín-Fernández. 2015. Atlas Serpientes de Venezuela: Una Visión Actual de su Diversidad. Dimacofi Negocios Avanzados S.A., Santiago, Chile.

Pazmiño-Otamendi, G. 2017. Rhinobothryum bovallii. In: O. Torres-Carvajal, G. Pazmiño-Otamendi, and D. Salazar-Valenzuela, Reptiles del Ecuador. Version 2019.0. Museo de Zoología, Pontificia Universidad Católica del Ecuador, Quito, Ecuador. <https://bioweb.bio/faunaweb/reptiliaweb/FichaEspecie/ Rhinobothryum\%20bovallii>.

Rojas-Morales, J.A. 2012. On the geographic distribution of Rhinobothyum bovalli, Anderson, 1916 in Colombia. A biogeographical perspective. Salamandra 48: 243-248.

Savage, J.M. 2002. The Amphibians and Reptiles of Costa Rica: A Herpetofauna Between Two Continents, Between Two Seas. University of Chicago Press, Chicago, USA.

Solórzano, A. 2004. Serpientes de Costa Rica: Distribución, taxonomía e historia natural. Heredia, Costa Rica: Instituto Nacional de Biodiversidad (INBio).

Velásquez-Múnera, E., A. Ortiz-Reyes, V.P. Páez, and G.E. Guzmán-Restrepo. 2008. Oviposition of Stenorrhina degenhardti (Serpentes: Colubridae) in a nest of Acromyrmex octospinosus (hymenoptera: formicidae). Actualidades Biológicas 30(88): 199-201.

Vitt, L.J., and L.D. Vangilder. 1983. Ecology of a snake community in northeastern Brazil. Amphibia-Reptilia 4: 273-296. 